\title{
Sodium silicate solutions from dissolution of glass wastes. Statistical analysis
}

\author{
M. Torres-Carrasco ${ }^{\mathrm{a}} \bowtie$, J.G. Palomo ${ }^{\mathrm{b}}$, F. Puertas ${ }^{\mathrm{a}}$ \\ a. Eduardo Torroja Institute for Construction Sciences (IETcc-CSIC) (Madrid, Spain) \\ b. School of Building Engineering (EUATM-UPM) (Madrid, Spain) \\ $\triangle$ mtorres@ietcc.csic.es
}

\author{
Received 4 July 2013 \\ Accepted 9 December 2013 \\ Available on line 05 May 2014
}

\begin{abstract}
It has studied the solubility process of four different waste glasses (with different particle sizes, $<45 \mu \mathrm{m}$ and $>125 \mu \mathrm{m}$ ) in alkaline solutions $\left(\mathrm{NaOH}\right.$ and $\left.\mathrm{NaOH} / \mathrm{Na}_{2} \mathrm{CO}_{3}\right)$ and water as a reference and under different conditions of solubility (at room temperature, at $80^{\circ} \mathrm{C}$ and a mechano-chemical process). Have established the optimal conditions of solubility and generation of sodium silicates solutions, and these were: the smaller particle size $(<45 \mu \mathrm{m})$, with $\mathrm{NaOH} / \mathrm{Na}_{2} \mathrm{CO}_{3}$ solution and with temperature during 6 hours of stirring time. The statistical analyses of the results give importance to the studied variables and the interactions. Through ${ }^{29} \mathrm{Si}$ NMR MAS it has confirmed the formation after dissolution processes of monomeric silicate, suitable for use as an activator in the preparation of alkaline cements and concretes.
\end{abstract}

KEYWORDS: Waste glass; Alkaline cements; Solubility; Sodium silicate hydrates (waterglass); Alkaline activators

Citation / Citar como: Torres-Carrasco, M.; Palomo, J.G.; Puertas, F. (2014) Sodium silicate solutions from dissolution of glass wastes: Statistical analysis. Mater. Construcc. 64 [314], e014 http://dx.doi.org/10.3989/mc.2014.05213

RESUMEN: Disoluciones de silicato sódico procedentes del tratamiento de residuos vítreos Estudio estadístico. Se ha estudiado el proceso de solubilidad de cuatro diferentes residuos vítreos (con distintas granulometrías, $<45 \mu \mathrm{m}$ y $>125 \mu \mathrm{m}$ ) en disoluciones alcalinas de $\mathrm{NaOH}$ y $\mathrm{NaOH} / \mathrm{Na}_{2} \mathrm{CO}_{3}$ y agua como medio de referencia y bajo distintas condiciones de solubilidad (a temperatura ambiente, a $80^{\circ} \mathrm{C}$ y con un proceso mecano-químico). Se han establecido las condiciones óptimas de solubilidad y generación de disoluciones de silicato sódico, y estas son: menor tamaño de partícula del residuo vítreo (inferior a $45 \mu \mathrm{m}$ ), con la disolución de $\mathrm{NaOH} / \mathrm{Na}_{2} \mathrm{CO}_{3}$ y tratamiento térmico a $80^{\circ} \mathrm{C}$ durante 6 horas de agitación. El análisis estadístico realizado a los resultados obtenidos da importancia a las variables estudiadas y a las interacciones de las mismas. A través de ${ }^{29} \mathrm{Si} \mathrm{RMN}$ MAS se ha confirmado la formación, tras los procesos de disolución, de un silicato monomérico, apto para su utilización como activador en la preparación de cementos y hormigones alcalinos.

PALABRAS CLAVE: Residuos vítreos; Cementos alcalinos; Solubilidad; Silicatos sódico hidratados (waterglass); Activadores alcalinos

Copyright: (C) 2014 CSIC. This is an open-access article distributed under the terms of the Creative Commons Attribution-Non Commercial (by-nc) Spain 3.0 License.

\section{INTRODUCTION}

The amount of urban and industrial waste has increased the world over in the last few decades. In the late twentieth century, urban waste was treated primarily in incineration plants, a technology that raised serious environmental problems, primarily associated with the emission of carbon dioxide and toxic particles. This situation led to the implementation of waste management and sorting policies in 
most highly developed countries. Hence the importance attached to recycling and valorization of all manner of industrial waste and by-products, to enhance environmental protection.

Waste glass collection and management are increasingly common elements of environmental policy in the developed world. In 1994, approximately 9.2 million metric tons of postconsumer glass was discharged in the municipal waste stream in the United States. Approximately 8.1 million metric tons or $80 \%$ of this waste glass was container glass $(1,2)$. In Hong Kong, there are $44000 \mathrm{t}$ of waste glass generated from domestic sources per year. In addition, there are $20000 \mathrm{t}$ of waste glass annually generated from commercial sources. Of the total $64000 \mathrm{t}$ of waste glass, only about $8000 \mathrm{t}$ are recycled and reused although about $50000 \mathrm{t}$ of waste glass are technically recoverable (3). In Spain, a total of $712 \mathrm{t}$ of glass containers or $15.1 \mathrm{~kg}$ of glass waste per inhabitant were deposited in streetside bins in 2010 (4). This statistic is encouraging, bearing in mind that glass container consumption has declined by $5.7 \%$ in recent years. In that same year, a further $2240 \mathrm{~kg}$ were taken from sorting plants, the second source of glass waste after street-side bins (4). Moreover, many of these waste glasses are currently disposed of at the landfills which are being filled much faster than expected. If the current trend of waste generation and disposal continues, our landfills will be exhausted by 2015 .

Glass comes in many shapes: as bottles, flasks or glazing for windows; flat or round; coloured or clear; and with or without ceramic or metal coating. Since its service life is nearly always very short despite its shape, it is typically reused or recycled. Glass waste must meet a series of requirements for reuse in the manufacture of other glass articles, however. The tendency is to collect and sort urban and industrial glass waste by type. Even so, the wide variety of materials and chemical compositions involved renders its reuse by conventional technological processes highly complex. As a result, from 10 to $30 \%$ of glass waste is not recyclable for these purposes and alternative valorisation pathways must be sought. All the existing technologies for recycling mixed glass waste involve crushing. The fragments obtained (1-8 $\mathrm{mm}$ fraction), blended in the form of powder (scantly reusable in glass manufacture), can be reused in construction in the following applications:

1. as pozzolanic additions to prepare Portland cements (5)

2. in the preparation of vitroceramic composites together with other industrial waste or byproducts, such as fly ash, slag and ceramic discards $(6,7)$

3 . in the preparation of composites with a polymer matrix (vehicle and pedestrian pavements) (8)
4. as the main component in the production of foam glass for thermal insulating materials (9)

5. as a prime material for synthesizing solid sodium silicates or purified silica.

The fifth application, addressed here, has been scantly studied. Very recent research by the authors $(10,11)$ has shown that sodium silicatebased urban glass waste may serve as an active component in the preparation of alkali-activated slag or fly ash cements. Moreover, the construction industry is presently very keen on developing new cements and construction materials, whose manufacture would be less energy-intensive and entail the emission of less polluting gas (primarily $\mathrm{CO}_{2}$ ) than conventional Portland cement manufacture. These cements are obtained by mixing amorphous silico-aluminates such as blast furnace slag, fly ash, metakaolin or volcanic rock, or blends of two or three of these materials, with highly alkaline solutions $\left(\mathrm{NaOH}, \mathrm{Na}_{2} \mathrm{CO}_{3}\right.$ or alkaline silicate hydrates) $(12-18)$. Inorganic polymer binders provide an alternative to traditional cements up to $80 \%$ less $\mathrm{CO}_{2}$ emissions, and are derived from industrial waste materials $(19,20)$.

Prior studies (21) showed that the predominant factor in the strength of these alkaline cements was the nature of the alkaline activator. Sodium silicate hydrate (waterglass) proved to be most effective. Bearing in mind that urban glass waste is an amorphous material whose chemical composition includes $\mathrm{SiO}_{2}(65-75 \%), \mathrm{CaO}(6-12 \%), \mathrm{Na}_{2} \mathrm{O}$ (12-15\%), $\mathrm{Al}_{2} \mathrm{O}_{3}(0.5-5 \%)$ and $\mathrm{Fe}_{2} \mathrm{O}_{3}(0.1-3 \%)$, it may be regarded as a potential (waterglass family) alkaline activator for blast furnace slag, fly ash or other aluminosilicates.

Soluble sodium silicates have been used in industry for a wide variety of applications. The raw materials for sodium silicate manufacture are soda ash and sand. Heated to $1100-1200^{\circ} \mathrm{C}$, the materials fuse and a glass forms upon cooling. This glass sold as anhydrous powder or dissolved in water at the manufacturing plant. The resulting solution, also known as "waterglass", may be sold as it is, or it may be causticized to form more alkaline solutions (22). Therefore, the process of synthesis of waterglass is costly and entails negative environmental effects because is necessary to reach high temperatures in the decarbonation of $\mathrm{Na}_{2} \mathrm{CO}_{3}$.

In regard to the chemistry of silica, there are numerous studies concerning the solubility of silicoaluminous materials, polymerization, colloidal and surface properties, etc (23). Key features of the glass, along with transparence, is the high chemical resistance. Due to its good qualities, always takes place more or less interaction between the glass and chemicals. Glasses are attacked in both aqueous acid and alkaline solutions, although the mechanisms of attack and the degree of corrosion 
are different in each case (24). Apparently, the solubility of these glass materials is high when the $\mathrm{pH}$ values are high (25-27). From $\mathrm{pH} 9$ to 10.7, there is an apparent increase in the solubility of amorphous silica, owing to the formation of silicate ion in addition to the monomer which is in equilibrium with the solid phase. Above $\mathrm{pH}$ 10.7, all the solid phase of amorphous silica dissolves to form soluble silicate, since at higher $\mathrm{pH}$ the concentration of $\mathrm{Si}$ $(\mathrm{OH})_{4}$ is greatly lowered by conversion to ionic species, so that no amorphous solid can remain in equilibrium. Moreover, the effect of temperature was also studied on the solubility of glass $(27,28)$, where an increase in the temperature favors the dissolution of the waste glass.

The objective of this paper is to study the possibility to generate solutions of sodium silicates (as potential waterglass solutions) by the solubility of different types of waste glass. Three for different dissolution processes have been applied: at room temperature $\left(22^{\circ} \mathrm{C} \pm 2^{\circ} \mathrm{C}\right)$, at $80^{\circ} \pm 2^{\circ} \mathrm{C}$ and by mechano-chemical ones. The final goal is to establish the optimal solubility conditions to see in further studies the feasibility of the use of waste glass as potential alkaline activators of materials such as slag or fly ash.

\section{EXPERIMENTAL PROGRAM}

\subsection{Materials and their characterisation}

Four types of pre-management glass waste were chosen: clear, green, brown and mixed. These materials were characterised with the following techniques:
- X-ray fluorescence (XRF): PHILIPS PW 2400 spectrometer fitted with a PW 2540 VTC sample changer; XRF readings calibrated and validated with certified reference materials

- X-ray diffraction (XRD): BRUKER AXS D8 Advance diffractometer fitted with a Lynxeye super speed RX detector, a 2.2-kW Cu anode and no monochromator. The scanning range, from 5 to $60^{\circ}$, was covered in a 24 minutes period. The instrument was set at $40 \mathrm{~kW}$ and $30 \mathrm{~mA}$ and the sample was not rotated during scanning.

- Fourier transform infrared spectroscopy (FTIR): ATIMATTSON Genesis FTIR-TM spectrometer, set to scan frequencies across a range of 4000 to $400 \mathrm{~cm}^{-1}$; solid samples pressed into $\mathrm{KBr}$ pellets, using $1.0 \mathrm{mg}$ of sample and $300 \mathrm{mg}$ of $\mathrm{KBr}$.

- ${ }^{29}$ Si NMR: BRUKER MSL 400 spectrometer operating at $79.49 \mathrm{MHz}$. For liquid samples ${ }^{29} \mathrm{Si}$ spectra not applied magic angle spinning (MAS).

The glass samples were crushed, ground and sieved to obtain three particle size fractions: i) $<45 \mu \mathrm{m}$; ii) $45-90 \mu \mathrm{m}$; iii) $>125 \mu \mathrm{m}$.

Table 1 gives the chemical composition (by XRF) of the glass waste for each particle size chosen for the study (from under 45 to over $125 \mu \mathrm{m}$ ). The XRF values showed that the proportions of the majority oxides $\left(\mathrm{SiO}_{2}, \mathrm{Na}_{2} \mathrm{O}\right.$ and $\left.\mathrm{CaO}\right)$ were similar across the entire range of particle sizes and types of glass. Some minor differences were detected in the trace elements, and specifically $\mathrm{Cr}$, which plays a role in glass hue (with higher levels in green, brown and mixed glass).

TABLE 1. XRF-determined chemical composition of glass waste $(\% \mathrm{wt})$

\begin{tabular}{|c|c|c|c|c|c|c|c|c|c|c|c|c|}
\hline \multirow[b]{3}{*}{$\%$ wt } & \multicolumn{12}{|c|}{ Glass type (particle sizes in $\mu \mathrm{m}$ ) } \\
\hline & \multicolumn{3}{|c|}{ Clear } & \multicolumn{3}{|c|}{ Green } & \multicolumn{3}{|c|}{ Brown } & \multicolumn{3}{|c|}{ Mixed } \\
\hline & $<45$ & $45-90$ & $>125$ & $<45$ & $45-90$ & $>125$ & $<45$ & $45-90$ & $>125$ & $<45$ & $45-90$ & $>125$ \\
\hline $\mathrm{SiO}_{2}$ & 71.4 & 70.8 & 70.9 & 70.7 & 70.2 & 71.3 & 70.7 & 70.9 & 69.9 & 70.7 & 71.0 & 71.2 \\
\hline $\mathrm{Al}_{2} \mathrm{O}_{3}$ & 1.7 & 1.8 & 1.7 & 2.1 & 2.0 & 2.0 & 2.1 & 2.1 & 2.5 & 2.0 & 2.1 & 2.2 \\
\hline $\mathrm{Fe}_{2} \mathrm{O}_{3}$ & 0.1 & 0.1 & 0.1 & 0.5 & 0.6 & 0.5 & 0.6 & 0.5 & 0.6 & 0.5 & 0.4 & 0.4 \\
\hline $\mathrm{MgO}$ & 3.2 & 3.2 & 3.1 & 1.1 & 1.1 & 1.1 & 0.9 & 1.0 & 0.8 & 1.2 & 1.2 & 1.2 \\
\hline $\mathrm{CaO}$ & 9.12 & 9.4 & 9.7 & 11.8 & 12.4 & 11.4 & 12.3 & 12.0 & 13.2 & 11.8 & 11.7 & 11.3 \\
\hline $\mathrm{Na}_{2} \mathrm{O}$ & 11.5 & 11.7 & 11.4 & 12.0 & 12.1 & 12.1 & 11.6 & 12.0 & 11.4 & 11.7 & 11.6 & 11.9 \\
\hline $\mathrm{K}_{2} \mathrm{O}$ & 2.6 & 2.6 & 2.7 & 1.0 & 1.1 & 1.0 & 1.1 & 1.0 & 1.2 & 1.1 & 1.1 & 1.1 \\
\hline $\mathrm{TiO}_{2}$ & 0.05 & 0.06 & 0.06 & 0.07 & 0.09 & 0.08 & 0.09 & 0.09 & 0.09 & 0.11 & 0.11 & 0.1 \\
\hline $\mathrm{P}_{2} \mathrm{O}_{5}$ & 0.03 & 0.03 & 0.03 & 0.04 & 0.04 & 0.04 & 0.04 & 0.04 & 0.05 & 0.04 & 0.04 & 0.04 \\
\hline $\mathrm{Cr}$ (ppm) & 112 & 33 & 81 & 415 & 703 & 673 & 378 & 440 & 428 & 471 & 499 & 503 \\
\hline $\mathrm{Ba}(\mathrm{ppm})$ & 285 & 58 & 103 & 242 & 277 & 135 & 305 & 388 & 212 & 318 & 485 & 373 \\
\hline $\mathrm{Pb}(\mathrm{ppm})$ & - & 1 & - & 20 & 40 & 35 & 28 & 35 & 33 & 132 & 139 & 140 \\
\hline $\mathrm{S}(\mathrm{ppm})$ & 341 & 257 & 277 & 64 & 47 & 65 & 74 & 71 & 67 & 165 & 184 & 177 \\
\hline $\mathrm{Cl}$ (ppm) & 88 & 68 & 81 & 84 & 87 & 95 & 110 & 102 & 96 & 189 & 198 & 214 \\
\hline
\end{tabular}




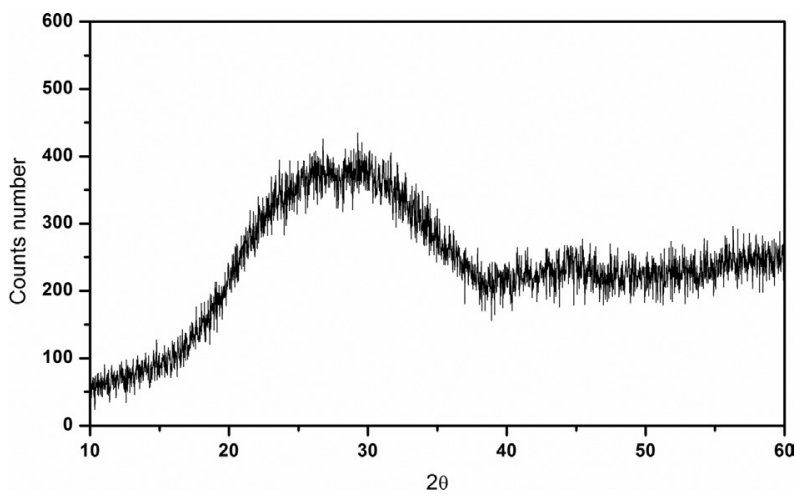

FIGURE 1. XRD diffractogram for the waste glass.

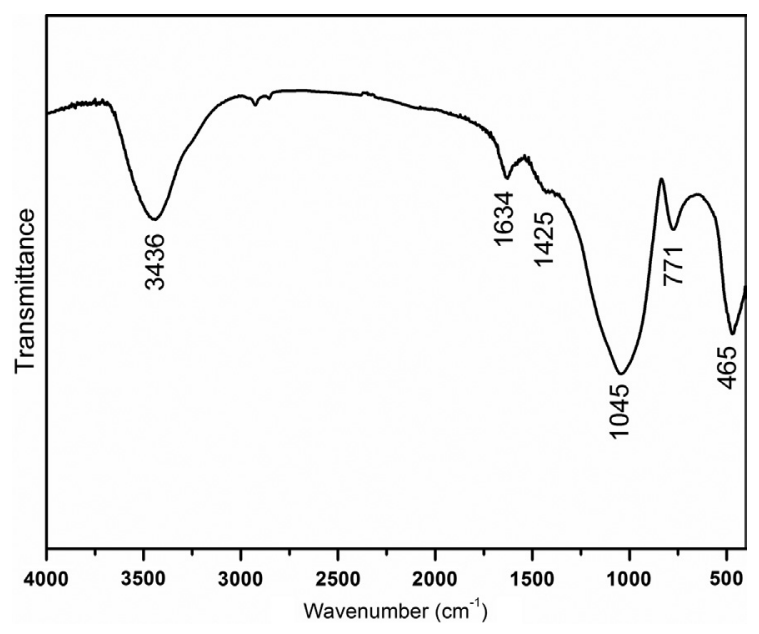

FIGURE 2. FTIR spectrum for waste glass.

The XRD mineralogical characterisation (see Figure 1) showed the glass to be an amorphous material, with low range structural order. Crystalline phases were not detected via XRD, consistent with the highly amorphous nature of the materials used in this study at $2 \theta$ values of around $20-40^{\circ}$, an indication of the vitrification of silicates, sodium silicate $\left(\mathrm{Na}_{2} \mathrm{SiO}_{3} \cdot \mathrm{nH}_{2} \mathrm{O}\right)$ and calcium silicate type phases, along with potassium and barium. The IR spectra for these glass waste (Figure 2) contained a wide and

TABLE 2. Assignment of FTIR bands on the spectrum for waste glass

\begin{tabular}{lc}
\hline Wavenumber $\left(\mathbf{c m}^{-1}\right)$ & Assigned to \\
\hline 3436 & reticular $\mathrm{v}-\mathrm{OH}$ \\
1634 & $\delta$ - $\mathrm{H}-\mathrm{O}-\mathrm{H}$ \\
1425 & $v_{3}\left(\mathrm{CO}_{3}^{2-}\right)$ \\
1045 & $v_{3}(\mathrm{Si}-\mathrm{O})$ asymmetric stretching \\
771 & $v \mathrm{Si}-\mathrm{O}$ (in the $\mathrm{SiO}_{4}$ tetrahedron $)$ \\
465 & $v_{4}(\mathrm{O}-\mathrm{Si}-\mathrm{O})$ bending vibrations \\
\hline
\end{tabular}

intense band at $900-1100 \mathrm{~cm}^{-1}$ associated with the $\mathrm{Si}-\mathrm{O}\left(\mathrm{v}_{3}(\mathrm{Si}-\mathrm{O})\right)$ asymmetric stretching vibrations in the $\mathrm{SiO}_{4}$ tetrahedral groups present in the silicates, and another at $450-470 \mathrm{~cm}^{-1}$ due to the $v_{4}(\mathrm{O}-\mathrm{Si}-\mathrm{O})$ bending vibrations in the $\mathrm{SiO}_{4}$ groups, likewise in the silicates. The assignment of the spectrum bands is listed in Table 2. The XRD and FTIR findings were practically identical in the four types of glass waste.

\subsection{Glass waste solubility trials in highly alkaline media}

The variables studied to determine the solubility of the four types of glass in highly alkaline media were: type of process, nature of the activating solution, particle size of the glass waste, temperature and process/solution time.

Glass solubility was determined in the following three processes:

a) At ambient temperature $\left(22 \pm 2^{\circ} \mathrm{C}\right)$

b) At high temperature $\left(80 \pm 2^{\circ} \mathrm{C}\right)$

c) By a mechano-chemical process (in a ball grinder) at ambient temperature.

Chemical process, which consisted of magnetic stirring at ambient $\left(22 \pm 2^{\circ} \mathrm{C}\right)$ temperature and a constant speed, was studied in the four types of glass specified. The solid: liquid ratio was $1 \mathrm{~g}$ of glass material per $100 \mathrm{~mL}$ of solution $(1: 100)$. These conditions were constant for the four types of glass and three particle sizes $(<45,45-90$ and $>125 \mu \mathrm{m})$. Stirring times of $10 \mathrm{~min}$ and 2,4 and $6 \mathrm{~h}$ were studied to determine the effect on the time on glass dissolution. The three dissolutions used were deionised water $(\mathrm{pH}=7)$, the reference, a $\mathrm{NaOH}$ solution $(\mathrm{pH}=13.8)$ and a $1: 1 \mathrm{NaOH} / \mathrm{Na}_{2} \mathrm{CO}_{3}$ solution $(\mathrm{pH}=13.6)$. The concentration of the two alkaline solutions was $4 \mathrm{M}$. A total of 144 trials were conducted to test all these variables in the four types of glass.

Dissolution trials for chemical process at $80^{\circ} \mathrm{C}$ were limited to the brown and mixed glass, based on the findings for chemical process at ambient temperature. All the other conditions remained unchanged: stirring times, glass particle size and the activating solutions $\left(\mathrm{NaOH}\right.$ and $\mathrm{NaOH} / \mathrm{Na}_{2} \mathrm{CO}_{3}$ at the same concentration as in chemical process at ambient temperature). Solution temperature was held steady at $80 \pm 2^{\circ} \mathrm{C}$. A total of 48 trials were conducted under these conditions.

Lastly, in the mechano-chemical process trials, the glass was ground in a steel ball grinder. In such procedures, the relationship between the size and number of balls and the solid: liquid ratio had an important effect on the solubility process. Several trials were run to establish the optimal conditions. The best grinding performance was found 
for $5 \mathrm{~g}$ of solid in $500 \mathrm{ml}$ of solution and $1 \mathrm{~kg}$ of balls (with a size distribution of approximately $2.5 \%$ of balls $20 \mathrm{~mm}$ in diameter; and $12.3 \%$ measuring $15 \mathrm{~mm}, 29.3 \%, 9 \mathrm{~mm}$ and $56 \%, 5 \mathrm{~mm}$ in diameter). As in the case of chemical stirring at $80^{\circ} \mathrm{C}$, only brown and green glass were studied, using the same particle size fractions and stirring times as established for the ambient temperature trials, and the same concentration of $\mathrm{NaOH}$ and $\mathrm{NaOH} / \mathrm{Na}_{2} \mathrm{CO}_{3}$ solutions as for chemical process at ambient temperature. A total of 48 trials were conducted.

All the solutions obtained were gravity filtered and brought to a known volume for subsequent ICP-AES laboratory analysis of elements $\mathrm{Si}, \mathrm{Al}, \mathrm{Ca}$ and $\mathrm{Mg}$. The analyses were conducted in a VARIAN 725-ES inductively coupled plasma atomic emission spectrometer.

The objective of studying all these variables was to determine the type of process, type of glass (clear, green, brown or mixed), particle size of the glass waste and type of activating solution that yielded the highest glass solubility. This information is essential to establishing the optimal conditions for obtaining sodium silicates, possible waterglass as family alkaline activators, from glass waste.

\subsection{Statistical analysis of the solubility values}

The experimental findings for each dissolution process were statistically corroborated. Variables and their respective levels were established to obtain a mathematical model able to determine the solubility of all the species present in the glass $(\mathrm{Si}, \mathrm{Al}, \mathrm{Ca}$ and $\mathrm{Mg}$ ) in a single equation accommodating all the variables. STATGRAPHICS Plus 5.1 software was used in this analysis.

The data were obtained, i.e., the response variables were determined, by running a full factorial model on the experimental findings. Model parameter significance was analysed with the F-test (Fischer's test). The general criterion applied was to accord significance to factors as well as binary and ternary interactions whose p-values at 95\% confidence were lower than $<0.05$.

Once the significant factors were determined, the equation parameters were estimated and the model initially proposed was validated. Further to the model, the variability found in a response variable is attributed to the sum of a series of terms assigned to each factor studied and its binary and ternary interactions. In addition to the variability attributed to the factors studied, the model envisages a term representing the variability due to experimental error. In the present study, where interactions $>3$ were assumed to be nil, the equation [1] developed to define the model, a priori, was as follows:

$$
\begin{aligned}
\mathrm{y}_{\mathrm{ijkl}}= & \mu+\mathrm{A}_{\mathrm{i}}+\mathrm{B}_{\mathrm{j}}+\mathrm{C}_{\mathrm{k}}+\mathrm{D}_{1}+(\mathrm{AB})_{\mathrm{ijj}}+(\mathrm{AC})_{\mathrm{ik}}+(\mathrm{AD})_{\mathrm{jl}} \\
& +(\mathrm{BC})_{\mathrm{jk}}+(\mathrm{BD})_{\mathrm{il}}+(\mathrm{CD})_{\mathrm{kl}}+(\mathrm{ABC})_{\mathrm{ijk}}+(\mathrm{ABD})_{\mathrm{i}} \\
& +(\mathrm{ACD})_{\mathrm{ikl}}+(\mathrm{BCD})_{\mathrm{jk} \mathrm{l}}+\varepsilon_{\mathrm{ijkl}}
\end{aligned}
$$

where $\mathbf{y}_{\mathrm{ijk}}$ is the estimated value of the response variable at levels $\mathbf{i}, \mathbf{j}, \mathbf{k}$ and $\mathbf{I}$ for the factors studied; $\mu$ is a scale factor indicating the mean of the estimated value; $\mathbf{A}_{\mathbf{i}}, \mathbf{B}_{\mathrm{i}}, \mathbf{C}_{\mathbf{k}}$, and $\mathbf{D}_{1}$ represent the effects of the change in factor values on the response variable; $(\mathrm{AB})_{\mathrm{ij}},(\mathrm{AC})_{\mathrm{ik}},(\mathrm{AD})_{\mathrm{il}},(\mathrm{BC})_{\mathrm{ik}},(\mathrm{BD})_{\mathrm{il}}$ and $(\mathrm{CD})_{\mathrm{kl}}$ represent the effect of the binary interactions between factors on the response variable; eijkl, which represents the random measuring error, is independent of the factors and levels studied, subject to the assumption that $\varepsilon_{\mathrm{ijk} 1} \approx \mathrm{N}\left(0, \sigma^{2}\right)$; and $\sigma^{2}$ is the variance in the experimental error estimated from the available degrees of freedom, given that the interactions of an order higher than three are regarded as nil.

Table 3 lists the four factors studied in the factorial design for the experiments conducted, along with the associated levels for chemical activation at ambient temperature (for a total of 144 trials). Fewer levels of some of these factors were defined for chemical at $80^{\circ} \mathrm{C}$ and mechano-chemical processes (see Table 4).

The model was validated by plotting the experimental against the expected values. The model is valid when the points on the graph obtained are randomly distributed, i.e., where no pattern emerges.

TABLE 3. Factors studied and levels associated with each in chemical process at ambient temperature

\begin{tabular}{llcccc}
\hline Factor & Definition & \multicolumn{4}{c}{ Associated level } \\
\hline A & Type of & Clear & Green & Brown & Mixed \\
& glass & $\mathrm{N}_{\mathrm{A}}=(1)$ & $\mathrm{N}_{\mathrm{A}}=(2)$ & $\mathrm{N}_{\mathrm{A}}=(3)$ & $\mathrm{N}_{\mathrm{A}}=(4)$ \\
$\mathrm{B}$ & Particle & $<45 \mu \mathrm{m}$ & $45-90 \mu \mathrm{m}$ & $>125 \mu \mathrm{m}$ \\
& size & $\mathrm{N}_{\mathrm{B}}=(1)$ & \multicolumn{2}{c}{$\mathrm{N}_{\mathrm{B}}=(2)$} & $\mathrm{N}_{\mathrm{B}}=(3)$ \\
$\mathrm{C}$ & Stirring & 10 min & 2 hours & 4 hours & 6 hours \\
& time & $\mathrm{N}_{\mathrm{C}}=(1)$ & $\mathrm{N}_{\mathrm{C}}=(2)$ & $\mathrm{N}_{\mathrm{C}}=(3)$ & $\mathrm{N}_{\mathrm{C}}=(4)$ \\
$\mathrm{D}$ & Activating & $\mathrm{H}_{2} \mathrm{O}$ & $\mathrm{NaOH}$ & $\mathrm{NaOH}^{2}$ \\
& solution & $\mathrm{N}_{\mathrm{D}}=(1)$ & \multicolumn{2}{c}{$\mathrm{N}_{\mathrm{D}}=(2)$} & $\mathrm{Na}_{2} \mathrm{CO}_{3}$ \\
& & & & & $\mathrm{~N}_{\mathrm{D}}=(3)$ \\
\hline
\end{tabular}

\begin{tabular}{|c|c|c|c|c|c|}
\hline Factor & Definition & \multicolumn{4}{|c|}{ Associated level } \\
\hline A & $\begin{array}{l}\text { Type of } \\
\text { glass }\end{array}$ & \multicolumn{2}{|c|}{$\begin{array}{c}\text { Brown } \\
\mathrm{N}_{\mathrm{A}}=(3)\end{array}$} & \multicolumn{2}{|c|}{$\begin{array}{c}\text { Mixed } \\
\mathrm{N}_{\mathrm{A}}=(4)\end{array}$} \\
\hline B & $\begin{array}{l}\text { Particle } \\
\text { size }\end{array}$ & $\begin{array}{l}<45 \mu \mathrm{m} \\
\mathrm{N}_{\mathrm{B}}=(1)\end{array}$ & & $\begin{array}{l}45-90 \mu \mathrm{m} \\
\mathrm{N}_{\mathrm{B}}=(2)\end{array}$ & $\begin{array}{l}>125 \mu \mathrm{m} \\
\mathrm{N}_{\mathrm{B}}=(3)\end{array}$ \\
\hline $\mathrm{C}$ & $\begin{array}{l}\text { Stirring } \\
\text { time }\end{array}$ & $\begin{array}{c}10 \min \\
\mathrm{N}_{C}=(1)\end{array}$ & $\begin{array}{l}2 \text { hours } \\
\mathrm{N}_{\mathrm{C}}=(2)\end{array}$ & $\begin{array}{l}4 \text { hours } \\
\mathrm{N}_{\mathrm{C}}=(3)\end{array}$ & $\begin{array}{l}6 \text { hours } \\
\mathrm{N}_{\mathrm{C}}=(4)\end{array}$ \\
\hline $\mathrm{D}$ & $\begin{array}{l}\text { Activating } \\
\text { solution }\end{array}$ & \multicolumn{2}{|c|}{$\begin{array}{l}\mathrm{NaOH} \\
\mathrm{N}_{\mathrm{D}}=(2)\end{array}$} & \multicolumn{2}{|c|}{$\begin{array}{c}\mathrm{NaOH} / \mathrm{Na}_{2} \mathrm{CO}_{3} \\
\mathrm{~N}_{\mathrm{D}}=(3)\end{array}$} \\
\hline
\end{tabular}

TABLE 4. Factors studied and levels associated with each in chemical process at $80^{\circ} \mathrm{C}$ and mechanical-chemical process 


\section{RESULTS AND DISCUSSION}

\subsection{Glass waste solubility under different conditions}

The formation of sodium silicate solutions from the dissolution of glass waste is followed by the content of $\mathrm{SiO}_{2}$ dissolved from these wastes by the different methods applied. The Na ions content cannot be used because the alkaline solutions used were $\mathrm{NaOH}$ or $\mathrm{NaOH} / \mathrm{Na}_{2} \mathrm{CO}_{3}$. The main analytical and statistical results obtained according to the methods used are presented below.

\subsubsection{Ambient temperature $\left(22 \pm 2^{\circ} \mathrm{C}\right)$ process}

In most cases where glass is exposed to chemical attack, the medium is aqueous. The mechanism governing glass-water interaction must consequently be the first question addressed. Contact with the aqueous medium induces an exchange of sodium and hydrogen ions. Since the latter are present in water in equilibrium with $\mathrm{OH}^{-}$ions, this exchange governs dissolution (24). As Figure 3 shows, the solubility of the silicon oxide present in the glass rose with stirring time, irrespective of particle size. Nonetheless, solubility was highest when the glass particle size was under 45 microns, for the smaller the particle size the greater the specific surface and consequently the more intense the contact between the solution and the glass. The result is higher solubility.

Highly alkaline attacks are governed by a different mechanism, in which the $\mathrm{OH}^{-}$groups are predominant, further to the following reactions (24) [2]:

$$
\equiv \mathrm{Si}-\mathrm{O}-\mathrm{Si} \equiv+\mathrm{OH}^{-} \rightarrow \equiv \mathrm{Si}-\mathrm{OH}+\equiv \mathrm{Si}-\mathrm{O}^{-}
$$

Unsaturated $\equiv \mathrm{Si}-\mathrm{O}^{-}$groups may react with water molecules and form new silanol groups and more $\mathrm{OH}^{-}$groups [3]:

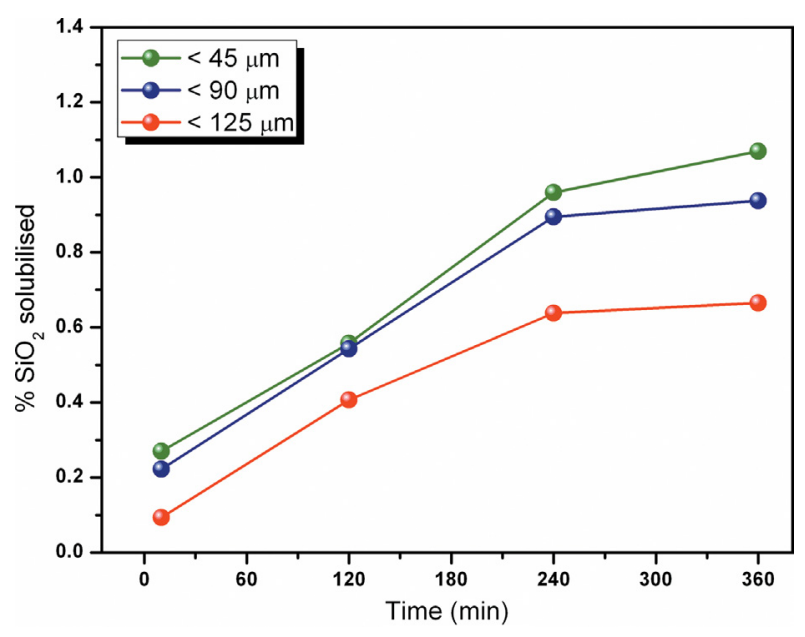

Figure 3. Percentage of $\mathrm{SiO}_{2}$ solubilised in clear glass in water. Effect of glass particle size.

$$
\equiv \mathrm{Si}-\mathrm{O}^{-}+\mathrm{H}_{2} \mathrm{O} \rightarrow \equiv \mathrm{Si}-\mathrm{OH}+\mathrm{OH}^{-}
$$

The reaction between the glass and the $\mathrm{OH}^{-}$ groups always hydrolyses oxygen bridges, partially destroying the network. For that reason, glass is much less resistant to alkaline than acidic media. In alkaline media, glass may be said to be depolymerised, resulting in total destruction of its network and gradual solubilisation.

Figure 4 shows the solubility of the four types of glass in the two alkaline media $(\mathrm{NaOH}$ and $\mathrm{NaOH} /$ $\mathrm{Na}_{2} \mathrm{CO}_{3}$ ) for glass particle sizes of under $45 \mu \mathrm{m}$. These findings confirmed the greater solubility of $\mathrm{SiO}_{2}$ and $\mathrm{Al}_{2} \mathrm{O}_{3}$ (forming oxides) in alkaline media than in water. In $\mathrm{NaOH}$, solubility was 16 to $43 \%$ higher than in water, depending on the type of glass. When the solution $\mathrm{pH}$ was raised (using $\mathrm{NaOH} /$ $\mathrm{Na}_{2} \mathrm{CO}_{3}$ or $\mathrm{NaOH}$ ), the amount of $\mathrm{SiO}_{2}$ and $\mathrm{Al}_{2} \mathrm{O}_{3}$ extracted rose substantially, due to network destruction after the $\mathrm{Si}-\mathrm{O}-\mathrm{Si}$ and $\mathrm{Al}-\mathrm{O}-\mathrm{Al}$ bonds were broken. The differences between the two solutions were significant: $\mathrm{SiO}_{2}$ solubility was 12 to $53 \%$ higher and $\mathrm{Al}_{2} \mathrm{O}_{3}$ solubility 17 to $54 \%$ higher with $\mathrm{NaOH} /$ $\mathrm{Na}_{2} \mathrm{CO}_{3}$ than with $\mathrm{NaOH}$ (Table 5). However, the difference between both $\mathrm{pH}$ values was not very remarkable but in this case; it is possible that other determining factors, such as the presence of a common ion $\left(\mathrm{Na}^{+}\right)$or the presence of carbonates contributed to dissolve a higher amount of glass (33).

As Figure 4 shows, the $\mathrm{Mg}$ and $\mathrm{Ca}$ oxides, regarded as network modifiers on the grounds of their electronegative potential values (29), failed to exhibit very high solubility over time. Because of their higher solubility (lower $\mathrm{Ca}-\mathrm{O}$ and $\mathrm{Mg}-\mathrm{O}$ bond energy than in $\mathrm{Al}-\mathrm{O}$ and $\mathrm{Si}-\mathrm{O})$, they dissolved from the time of initial contact between the alkaline solution and the glass.

Another interesting finding at ambient temperature was that glass solubility was very low and similar for the four types of glass studied (Figure 4). For that reason, the subsequent high temperature and mechano-chemical trials were conducted using only two types (brown and mixed) of glass.

\section{- Chemical process at ambient temperature: statistical analysis.}

The statistical significance for oxide solubility in the four factors studied (see Table 3) and their binary and ternary interactions was found by analysing the F-test results on variance in the experimental findings. Table 6 shows the $95 \%$ confidence level p-values obtained for $\mathrm{Si}, \mathrm{Al}, \mathrm{Ca}$ and $\mathrm{Mg}$ oxide solubility in the chemical process at ambient temperature trials. Significance was attributed to the factors and binary and ternary interactions with p-values of under 0.05 .

The findings revealed that not all four factors studied were statistically significant for all the oxides. For $\mathrm{SiO}_{2}$, the four factors were found to be statistically 

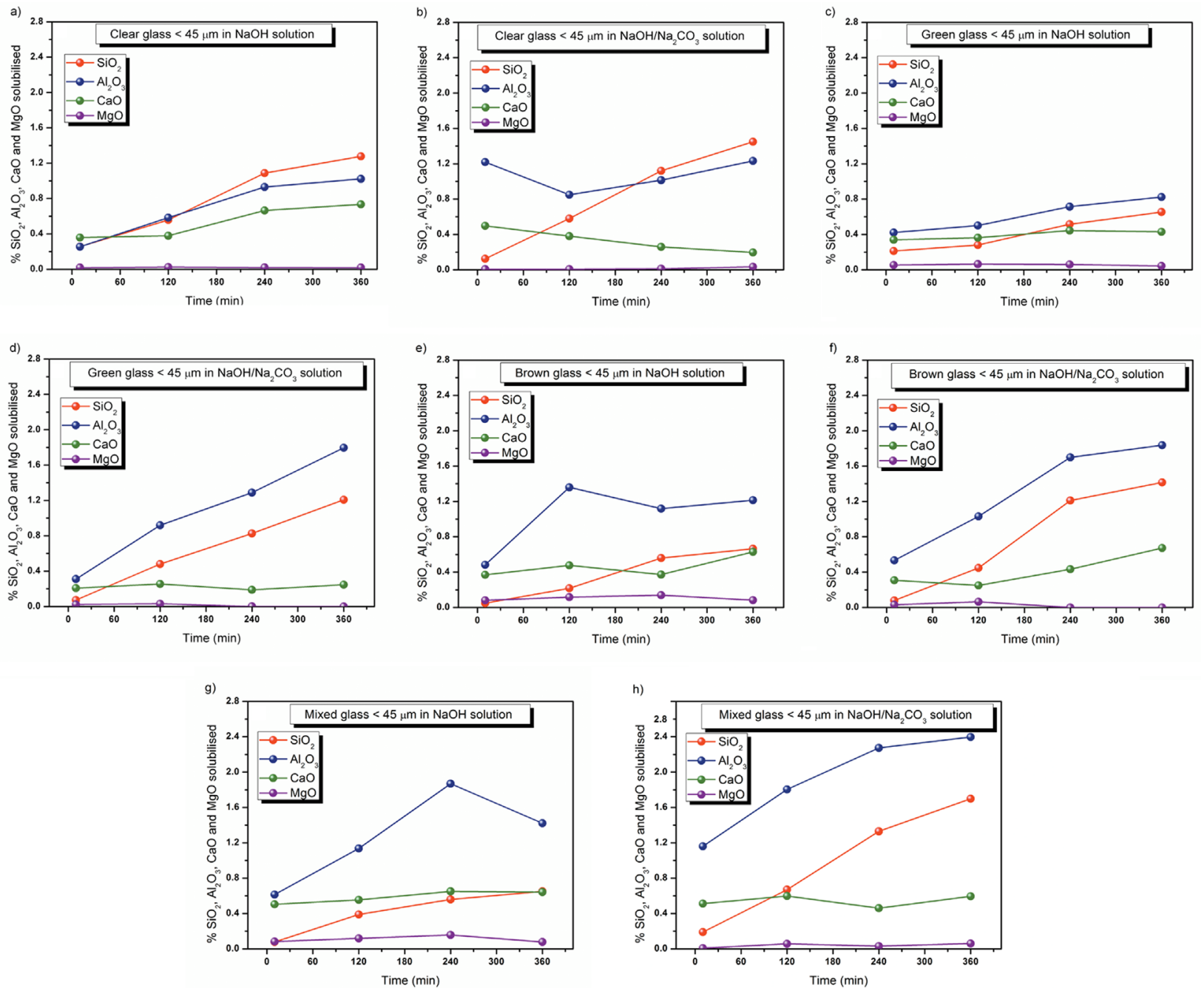

Figure 4. Chemical process at ambient $\mathrm{T}$. Solubility of $\mathrm{Si}, \mathrm{Al}, \mathrm{Ca}$ and $\mathrm{Mg}$ oxides present in the four types of glass in alkaline media $\left(\mathrm{NaOH}\right.$ and $\left.\mathrm{NaOH} / \mathrm{Na}_{2} \mathrm{CO}_{3}\right)$.

significant. The statistical analysis identified the conditions for each variable that optimised oxide solubility (6 $\mathrm{h}$ of activation, waste particle size $<45 \mu \mathrm{m}, \mathrm{NaOH} /$ $\mathrm{Na}_{2} \mathrm{CO}_{3}$ solution and clear-mixed glass: see Figure 5). All the binary interactions proved to be statistically significant. The explanation lies in the fact that even

TABLE 5. $\mathrm{SiO}_{2}\left(\%\right.$ wt. of $\mathrm{SiO}_{2}$ total $)$ and $\mathrm{Al}_{2} \mathrm{O}_{3}(\%$ wt. of $\mathrm{Al}_{2} \mathrm{O}_{3}$ total) after 6 hours of stirring in $\mathrm{H}_{2} \mathrm{O}, \mathrm{NaOH}$ and $\mathrm{NaOH} / \mathrm{Na}_{2} \mathrm{CO}_{3}$ (particle size $\left.<45 \mu \mathrm{m}\right)$

\begin{tabular}{lccccc}
\hline Glass & $\begin{array}{c}\mathrm{SiO}_{2} \\
\mathbf{i n}_{\mathbf{2}} \mathbf{O} \\
(\%)\end{array}$ & $\begin{array}{c}\mathrm{SiO}_{2} \text { in } \\
\mathbf{2 a O H} \\
(\%)\end{array}$ & $\begin{array}{c}\mathrm{SiO}_{2} \text { in } \\
\mathbf{N a O H} / \\
\mathbf{N a}_{2} \mathbf{C O}_{3}(\%)\end{array}$ & $\begin{array}{c}\mathrm{Al}_{2} \mathbf{O}_{3} \text { in } \\
\mathbf{N a O H} \\
(\%)\end{array}$ & $\begin{array}{c}\mathrm{Al}_{2} \mathbf{O}_{3} \text { in } \\
\mathbf{N a O H} / \\
\mathbf{N a}_{2} \mathbf{C O}_{3}(\%)\end{array}$ \\
\hline $\mathrm{C}$ & 1.061 & 1.277 & 1.449 & 1.022 & 1.233 \\
$\mathrm{G}$ & 0.436 & 0.654 & 1.208 & 0.823 & 1.796 \\
$\mathrm{~B}$ & 0.380 & 0.665 & 1.415 & 1.215 & 1.836 \\
$\mathrm{M}$ & 0.439 & 0.651 & 1.229 & 1.421 & 2.397 \\
\hline
\end{tabular}

$\mathrm{C}=$ Clear, $\mathrm{G}=$ Green, $\mathrm{B}=$ Brown, $\mathrm{M}=$ Mixed. the slightest change in the levels of any of the main factors altered the final result. Indeed, in chemical process at ambient temperature the solubility values were so low that any change would be highly significant. This explanation is equally applicable to the ternary interactions $(\mathrm{ABC}, \mathrm{ABD}$ and $\mathrm{BCD})$.

Glass type, stirring time and the type of activating solution (A, C and D, respectively) were the significant factors for aluminium and magnesium solubility but particle size (factor B) was not significant for either of these compounds (see Table 6). In all three of these oxides, the energy in the bond between the oxide and the respective ion $\left(\mathrm{Al}^{3+}, \mathrm{Ca}^{2+}\right.$ or $\left.\mathrm{Mg}^{2+}\right)$ was lower than between oxygen and Si. As a result, their greater solubility was specific surface-independent, lessening the role of particle size. One of the statistically significant binary interactions, stirring timetype of solution (interaction CD), was particularly prominent in the three cases. The inference is that regardless of the oxide used, its solubility always 
TABLE 6. P-values for oxide solubility in waste glasses subjected to chemical process at ambient temperature

\begin{tabular}{|c|c|c|c|}
\hline Oxide & Order of factors & Significant binary interactions & Significant ternary interactions \\
\hline $\mathrm{SiO}_{2}$ & $\begin{array}{c}* \mathbf{*} ;{ }^{*} * \mathbf{B} ; * \mathbf{C} ; * \mathbf{D} \\
* * 0.0000 ; 0.0000 ; 0.0000 ; 0.0000\end{array}$ & 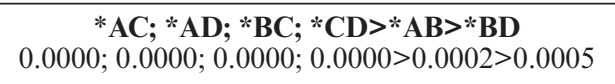 & $\begin{array}{c}* \mathbf{A C D}>* \mathbf{A B D}>* \mathbf{B C D}>\mathbf{A B C} \\
0.0000>0.0002>0.0013>0.0864\end{array}$ \\
\hline $\mathrm{Al}_{2} \mathrm{O}_{3}$ & $\begin{array}{c}{ }^{*} \mathbf{A} ;{ }^{*} \mathbf{C} ;{ }^{*} \mathbf{D}>\mathbf{B} \\
0.0000 ; 0.0000 ; 0.0000>0.1179\end{array}$ & $\begin{array}{c}* \mathrm{AD}>* \mathbf{C D}>\mathrm{AC}>\mathrm{AB}>\mathrm{BD}>\mathrm{BC} \\
0.0239>0.0348>0.1073>0.3127>0.3911>0.9139\end{array}$ & 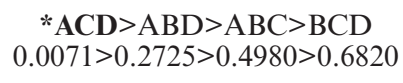 \\
\hline $\mathrm{CaO}$ & $\begin{array}{c}* \mathrm{*}>* \mathrm{~A}>\mathrm{B}>\mathrm{D} \\
0.0138>0.0215>0.0562>0.1246\end{array}$ & $\begin{array}{c}* \mathbf{C D}>* \mathbf{B C}>* \mathbf{B D}>\mathrm{AC}>\mathrm{AD}>\mathrm{AB} \\
0.0003>0.0194>0.0198>0.6960>0.8643>0.9213\end{array}$ & $\begin{array}{c}* \mathrm{BCD}>\mathrm{ABC}>\mathrm{ACD}>\mathrm{ABC} \\
0.0168>0.1385>0.4725>0.8592\end{array}$ \\
\hline $\mathrm{MgO}$ & $\begin{array}{c}* \mathbf{*} ; *{ }^{*} \mathbf{C} ; * \mathbf{D}>\mathbf{B} \\
0.0000 ; 0.0000 ; 0.0000>0.5269\end{array}$ & $\begin{aligned} & * \mathrm{AD}>* \mathrm{AC}>* \mathbf{C D}>\mathrm{BD}>\mathrm{BC}>\mathrm{AB} \\
0.0000 & >0.0006>0.0063>0.1098>0.1853>0.7686\end{aligned}$ & $\begin{aligned} * \mathrm{ACD} & >\mathrm{ABC}>\mathrm{ABD}>\mathrm{BCD} \\
0.0001 & >0.1306>0.1315>0.2436\end{aligned}$ \\
\hline
\end{tabular}

*The factors shown in bold are statistically significant.

$* *$ P-value at $95 \%$ confidence level.
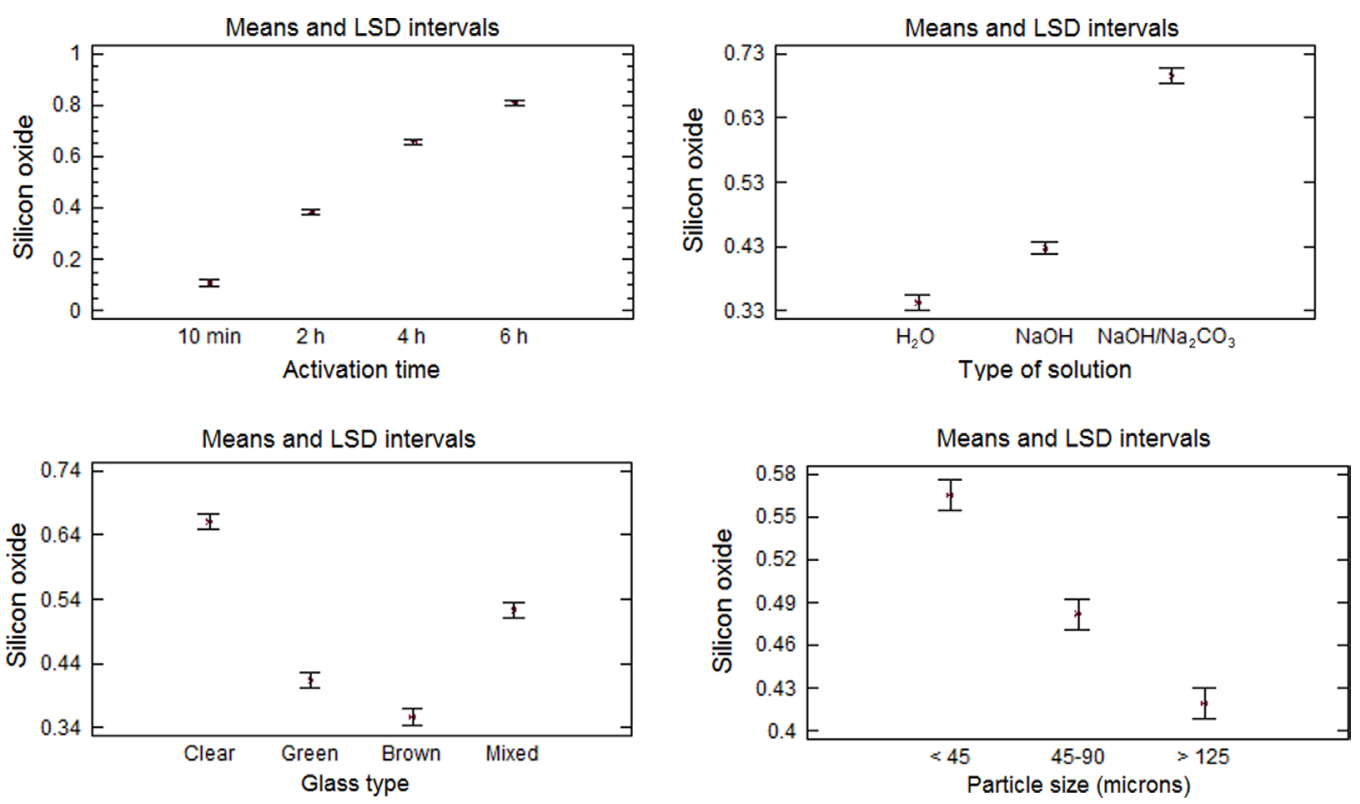

FIGURE 5. Significant main factors for $\mathrm{SiO}_{2}$ solubility in chemical process at ambient temperature.

depended on these two factors, although the values varied with the respective levels ( 10 minutes, 2,4 or 6 hours for stirring time and water, $\mathrm{NaOH}$ or $\mathrm{NaOH} /$ $\mathrm{Na}_{2} \mathrm{CO}_{3}$ for the type of solution). Interaction AD (glass type-activator type) also proved to be important, corroborating the above finding to the effect that $\mathrm{NaOH} / \mathrm{Na}_{2} \mathrm{CO}_{3}$ induced the highest solubility in all the oxides studied.

The ternary interactions for $\mathrm{Al}, \mathrm{Ca}$ and $\mathrm{Mg}$ were less significant than for silicon oxide, although interaction ACD (glass type-stirring time-type of activating solution) exhibited fairly high significance values.

\subsubsection{Chemical process at $80 \pm 2^{\circ} \mathrm{C}$}

Figure 6 shows the percentage of solubilized $\mathrm{Si}$, $\mathrm{Al}, \mathrm{Ca}$ and $\mathrm{Mg}$ oxides in brown and mixed glass after chemical process at $80^{\circ} \mathrm{C}$. As with chemical process at ambient temperature, glass particle size was a key factor in the solubility of silicon oxide, where the higher solubility was reached for particle size lower than $45 \mu \mathrm{m}$. Moreover, unlike what occurred at ambient temperature, the effect of temperature causes the particle size was significant for $\mathrm{Al}_{2} \mathrm{O}_{3}$ and $\mathrm{CaO}$. By contrast, the type of alkaline activator appeared to have a smaller impact at $80^{\circ} \mathrm{C}$ than at ambient temperature. In the high temperature trial, the solubilisation percentages were on the order of $60 \%$ for $\mathrm{SiO}_{2}$ and $55 \%$ for $\mathrm{Al}_{2} \mathrm{O}_{3}$ in all four types of glass (see Figure 6) and the amount of $\mathrm{SiO}_{2}$ dissolved similarly in the two types of glass for both alkaline solutions. Nonetheless, the $\mathrm{NaOH} / \mathrm{Na}_{2} \mathrm{CO}_{3}$ solution exhibited slightly better performance, dissolving 5 and $14 \%$ more of the $\mathrm{SiO}_{2}$ present in the brown and mixed glass, respectively. Given the higher solubility of the $\mathrm{Ca}$ and 
a)

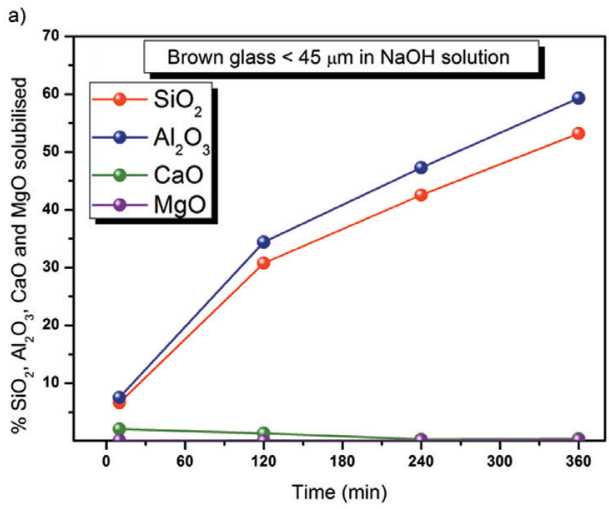

c)

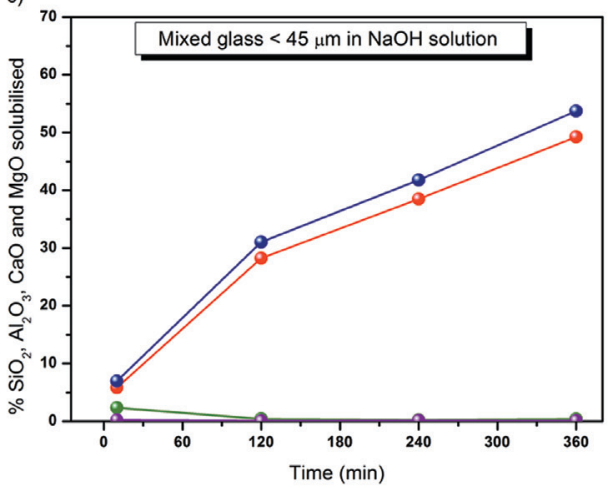

b)

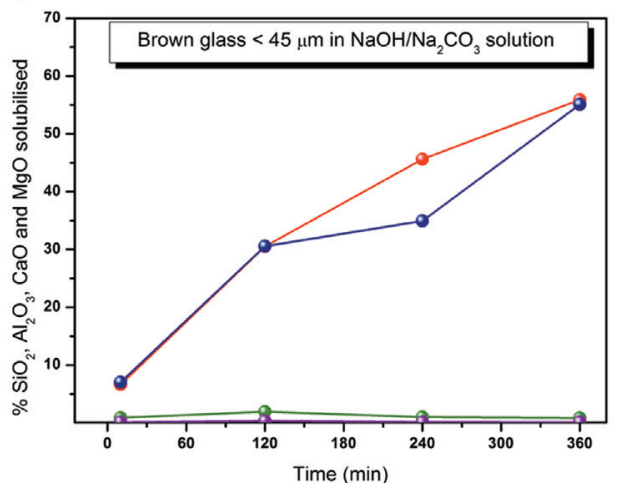

d)

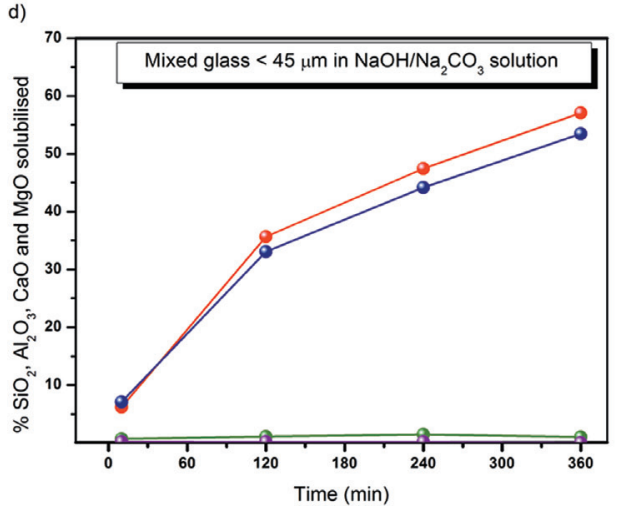

Figure 6. Chemical process at $80^{\circ} \mathrm{C}$ : $\mathrm{Si}, \mathrm{Al}, \mathrm{Ca}$ and $\mathrm{Mg}$ oxide solubility in brown and mixed glass in alkaline solutions.

Mg oxides, the percentages dissolved were similar to the values found at ambient temperature.

The findings for this type of process showed that temperature is a key variable in glass solubilisation.

\section{- $\quad$ Chemical process at $80^{\circ} \mathrm{C}$ : statistical analysis.}

The four factors studied in this experimental design are listed in Table 4 . According to the p-values obtained for process at $80^{\circ} \mathrm{C}$ (see Table 7), all the main factors were significant for $\mathrm{SiO}_{2}$ solubility. As above, the binary interactions were observed to follow two patterns, one in the network forming oxides $\left(\mathrm{SiO}_{2} \mathrm{y}\right.$ $\left.\mathrm{Al}_{2} \mathrm{O}_{3}\right)$ and the other in the modifiers $(\mathrm{CaO}$ y $\mathrm{MgO})$. In the former, the most significant binary interaction was particle size-stirring time (interaction BC). This finding was an indication that the smaller the particle size and the longer the stirring time, the higher was solubility (see Figure 7). As noted earlier, the use of $\mathrm{NaOH}$ or $\mathrm{NaOH} / \mathrm{Na}_{2} \mathrm{CO}_{3}$ had a small effect as the type of dissolution was significant when studied separately, but played a less important role in the binary interactions $\left(\mathrm{CD}=0.0531\right.$ for $\left.\mathrm{SiO}_{2}\right)$ than observed in chemical process at ambient temperature. Moreover,

TABLE 7. P-values for oxide solubility in waste glasses subjected to chemical process at $80^{\circ} \mathrm{C}$

\begin{tabular}{|c|c|c|c|}
\hline Oxide & Order of factors & Significant binary interactions & Significant ternary interactions \\
\hline $\mathrm{SiO}_{2}$ & $\begin{array}{c}* \mathbf{B} ;{ }^{*} \mathbf{C}>* \mathbf{D}>* \mathbf{A} \\
* * 0.0000 ; 0.0000>0.0002>0.0013\end{array}$ & 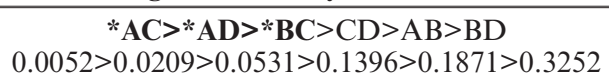 & None \\
\hline $\mathrm{Al}_{2} \mathrm{O}_{3}$ & $\begin{array}{c}{ }^{*} \mathbf{B} ;{ }^{*} \mathbf{C}>* \mathbf{D}>A \\
0.0000 ; 0.0000>0.0159>0.1089\end{array}$ & $\begin{array}{c}* \mathrm{BC}>\mathrm{BD}>\mathrm{CD}>\mathrm{AB}>\mathrm{AD}>\mathrm{AC} \\
0.0135>0.1377>0.1493>0.2102>0.3302>0.4788\end{array}$ & $\begin{array}{c}* \mathrm{ABD}>\mathrm{ACD}>\mathrm{BCD}>\mathrm{ABC} \\
0.0206>0.664>0.7910>0.8465\end{array}$ \\
\hline $\mathrm{CaO}$ & $\begin{array}{c}* \mathbf{C}>{ }^{*} \mathbf{B}>{ }^{*} \mathbf{D}>\mathrm{A} \\
0.0000>0.0026>0.0070>0.3741\end{array}$ & $\begin{aligned} & * \mathbf{C D}>* \mathbf{B D}>* \mathrm{AD}>* \mathbf{B C}>\mathrm{AB}>\mathrm{AC} \\
& 0.0000>0.0002>0.0004>0.0248>0.0647>0.2026\end{aligned}$ & 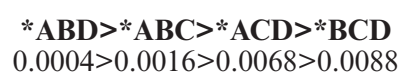 \\
\hline $\mathrm{MgO}$ & $\begin{array}{c}\mathrm{A}>\mathrm{C}>\mathrm{D}>\mathrm{B} \\
0.2395>0.3084>0.4143>0.8453\end{array}$ & $\begin{array}{c}* \mathbf{C D}>* \mathbf{B D}>* \mathbf{A D}>\mathrm{BC}>\mathrm{AC}>\mathrm{AB} \\
0.0029>0.0108>0.0175>0.6576>0.8739>0.9759\end{array}$ & None \\
\hline
\end{tabular}

*The factors shown in bold are statistically significant.

**P-value at $95 \%$ confidence level. 

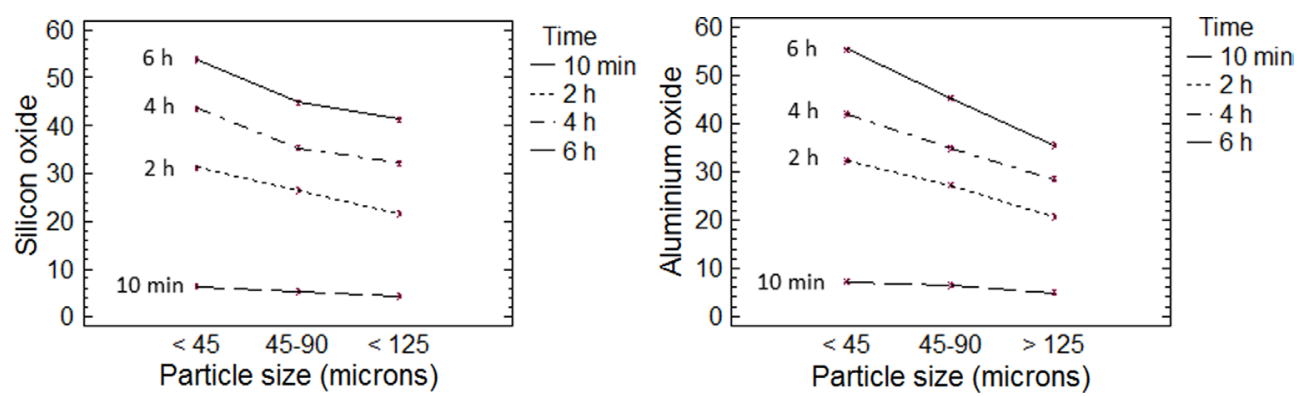

Figure 7. Particle size-activation time interaction graphs for $\mathrm{SiO}_{2}$ and $\mathrm{Al}_{2} \mathrm{O}_{3}$. Chemical process at $80^{\circ} \mathrm{C}$.

binary and ternary interactions were less significant here because with silicon and aluminium oxide solubility rates on the order of $60 \%$, a change in any of the variables studied had a lower impact on the end result. This confirmed the key role of temperature in oxide solubility.

\subsubsection{Mechano-chemical process at ambient temperature $\left(22 \pm 2^{\circ} \mathrm{C}\right)$}

The solubility values obtained for the four oxides in this process were very similar to those reported in the chemical process at room temperature. Figure 8 shows a comparative manner the three methods, confirming that chemical process at room temperature and mechanical-chemical dissolve the glass very similarly, while chemical method at $80 \pm 2^{\circ} \mathrm{C}$, is the most effective from the viewpoint of solubility of the glass.

- Mechano-chemical process at ambient temperature $\left(22 \pm 2^{\circ} \mathrm{C}\right)$ : statistical analysis.

Of the three processes studied, the mechanochemical procedure yielded the lowest levels of statistical significance, with no binary or ternary interactions in some cases (see Table 8). Contrary to the findings for type of activating solution in the two preceding methods, here factor D was not significant for silicon oxide dissolution, or in any
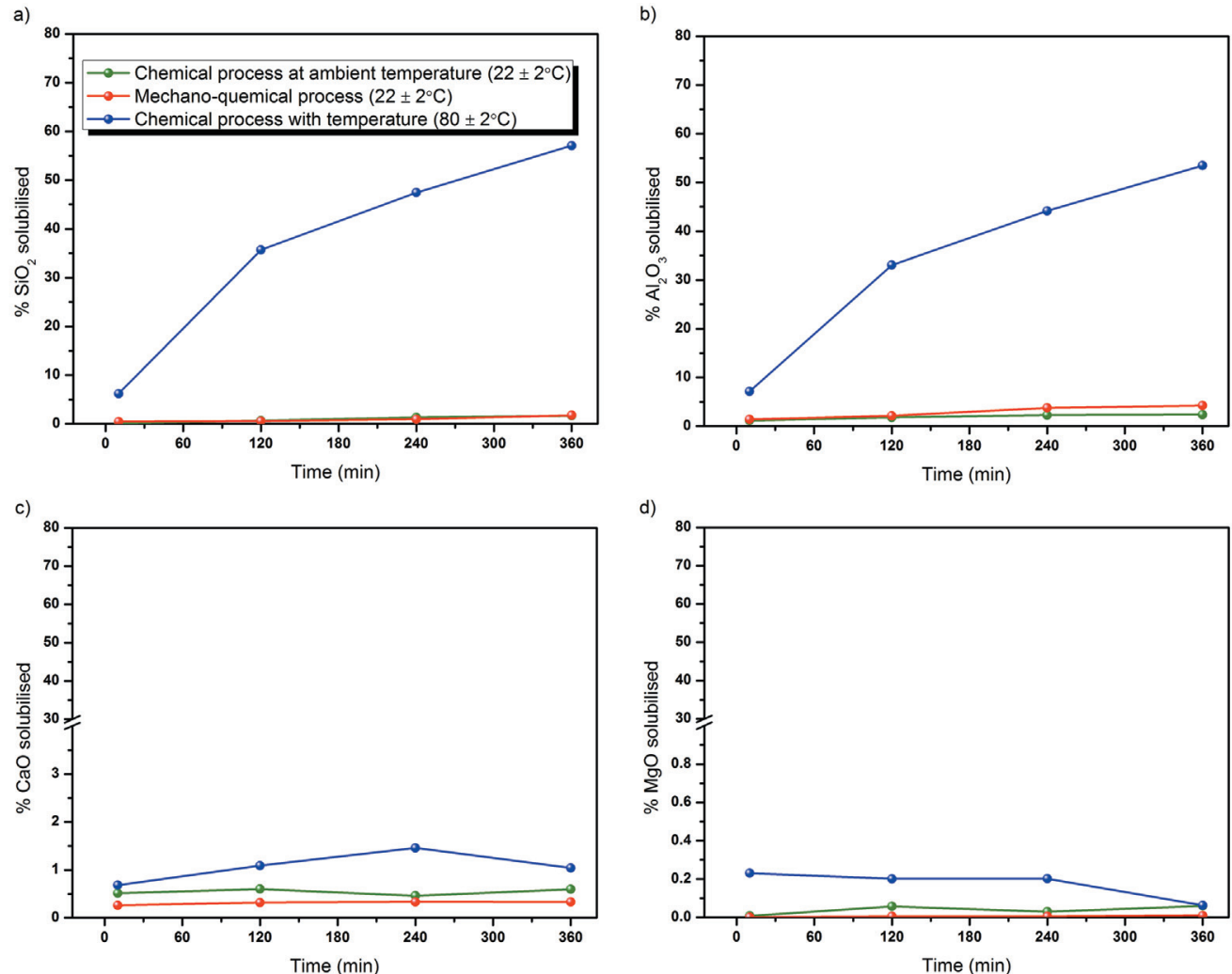

FIgURE 8. $\mathrm{Si}, \mathrm{Al}, \mathrm{Ca}$ and $\mathrm{Mg}$ oxide solubility in mixed glass: comparison of chemical and mechanical-chemical process at ambient temperature and chemical process at $80^{\circ} \mathrm{C}$. 
TABLE 8. P-values for oxide solubility in waste glasses subjected to mechanical-chemical process

\begin{tabular}{lccc}
\hline Oxide & Order of factors & Significant binary interactions & Significant ternary interactions \\
\hline $\mathrm{SiO}_{2}$ & ${ }^{*} \mathbf{B} ;{ }^{*} \mathbf{C}>* \mathbf{A}>\mathrm{D}$ & ${ }^{*} \mathrm{AC}>{ }^{*} \mathbf{B C}>\mathrm{AD}>\mathrm{BD}>\mathrm{CD}>\mathrm{AB}$ & None \\
& $* * 0.0000 ; 0.0000>0.0174>0.3157$ & $0.0309>0.0334>0.2749>0.5963>0.8245>0.8482$ & None \\
$\mathrm{Al}_{2} \mathrm{O}_{3}$ & ${ }^{*} \mathbf{C} ;{ }^{*} \mathbf{D}>\mathrm{A}>\mathrm{B}$ & None & \\
& $0.0000 ; 0.0000>0.4188>0.9492$ & ${ }^{*} \mathbf{C D}>* \mathbf{B C}>* \mathbf{B D}>\mathrm{AC}>\mathrm{AD}>\mathrm{AB}$ & $* \mathbf{B C D}>\mathrm{ABD}>\mathrm{ACD}>\mathrm{ABC}$ \\
$\mathrm{CaO}$ & ${ }^{*} \mathbf{C}>* \mathrm{~A}>\mathrm{B}>\mathrm{D}$ & None & $0.0168>0.1385>0.4725>0.8592$ \\
$\mathrm{MgO}$ & $0.0138>0.0215>0.0562>0.1246$ & $0.0003>0.0194>0.0198>0.6960>0.8643>0.9213$ & None \\
& $0.0000>0.0001>0.2124>0.8821$ & & \\
\hline
\end{tabular}

*The factors shown in bold are statistically significant.

**P-value at $95 \%$ confidence level.

binary interaction. No simple explanation can be given for this development, which may be associated with the grinding conditions and grinder characteristics. The statistical analysis of the other three oxides yielded findings that were not very different from the statistical results for the chemical procedures, although here calcium oxide was the sole compound to exhibit a third order interaction (interaction $\mathrm{BCD}$ ).

TABLE 9. Factors studied and associated levels for a full statistical analysis (for the three processes of dissolution)

\begin{tabular}{|c|c|c|c|c|c|}
\hline Factor & Definition & \multicolumn{4}{|c|}{ Associated level } \\
\hline A & $\begin{array}{l}\text { Type of } \\
\text { glass }\end{array}$ & \multicolumn{2}{|c|}{$\begin{array}{c}\text { Brown } \\
\mathrm{N}_{\mathrm{A}}=(3)\end{array}$} & \multicolumn{2}{|c|}{$\begin{array}{c}\text { Mixed } \\
\mathrm{N}_{\mathrm{A}}=(4)\end{array}$} \\
\hline B & $\begin{array}{l}\text { Particle } \\
\text { size }\end{array}$ & $\begin{array}{l}<45 \mu \mathrm{m} \\
\mathrm{N}_{\mathrm{B}}=(1)\end{array}$ & \multicolumn{2}{|c|}{$\begin{array}{c}45-90 \mu \mathrm{m} \\
\mathrm{N}_{\mathrm{B}}=(2)\end{array}$} & $\begin{array}{l}>125 \mu \mathrm{m} \\
\mathrm{N}_{\mathrm{B}}=(3)\end{array}$ \\
\hline $\mathrm{C}$ & $\begin{array}{l}\text { Stirring } \\
\text { time }\end{array}$ & $\begin{array}{l}10 \min \\
\mathrm{N}_{C}=(1)\end{array}$ & $\begin{array}{l}2 \text { hours } \\
\mathrm{N}_{C}=(2)\end{array}$ & $\begin{array}{l}4 \text { hours } \\
N_{C}=(3)\end{array}$ & $\begin{array}{l}6 \text { hours } \\
N_{C}=(4)\end{array}$ \\
\hline $\mathrm{D}$ & $\begin{array}{l}\text { Type of } \\
\text { activating } \\
\text { solution }\end{array}$ & \multicolumn{2}{|c|}{$\begin{array}{c}\mathrm{NaOH} \\
\mathrm{N}_{\mathrm{D}}=(2)\end{array}$} & \multicolumn{2}{|c|}{$\begin{array}{c}\mathrm{NaOH} / \mathrm{Na}_{2} \mathrm{CO}_{3} \\
\mathrm{~N}_{\mathrm{D}}=(3)\end{array}$} \\
\hline $\mathrm{E}$ & Process & $\begin{array}{l}\text { Chemical at } \\
\text { ambient T } \\
\mathrm{N}_{\mathrm{E}}=(1)\end{array}$ & $\begin{array}{l}\text { Mech } \\
\text { cher } \\
\mathrm{N}_{\mathrm{E}}\end{array}$ & $\begin{array}{l}\text { anical- } \\
\text { nical } \\
=(2)\end{array}$ & $\begin{array}{l}\text { Chemical } \\
\text { at } 80^{\circ} \mathrm{C} \\
\mathrm{N}_{\mathrm{E}}=(3)\end{array}$ \\
\hline
\end{tabular}

\subsection{Statistical analysis of the three different methods applied}

The statistical study performed to take the solubilisation methods used (Table 9) into consideration yielded significant values for the all main factors as well as the binary and ternary interactions (Table 10). As noted earlier, the effect of the process used played an important role in glass waste solubilisation and sodium silicates formation, for both network forming and modifying oxides.

According to the p-values, the solubilisation method used (factor E) was significant in all the oxides studied, both separately and in the binary and ternary interactions. While all the binary interactions were significant for $\mathrm{SiO}_{2}$ solubility, the interactions involving factor $\mathrm{E}$ were the most prominent. All the other main factors studied (A, B, C and D) were significant in binary and ternary interactions with factor E: in other words, regardless of the solubilisation process used, these factors would be altered. This reinforces the importance of temperature in the dissolution of $\mathrm{SiO}_{2}$ oxide in glass. Aluminium oxide behaved in much the same way as silicon oxide. The solubilisation process was likewise significant for the modifying oxides, although the type of solution used and stirring time prevailed over the other factors.

TABLE 10. P-values of the solubility of different oxides in waste glasses considering the dissolution process used

\begin{tabular}{|c|c|c|c|}
\hline Oxide & Order of factors & Significant binary interactions & $\begin{array}{l}\text { Significant ternary } \\
\text { interactions }\end{array}$ \\
\hline $\mathrm{SiO}_{2}$ & $\begin{array}{c}{ }^{*} \mathbf{B} ;{ }^{*} \mathbf{C} ;{ }^{*} \mathbf{D} ;{ }^{*} \mathbf{E}>* \mathbf{A} \\
* * 0.000 ; 0.000 ; 0.000 ; 0.000>0.0002\end{array}$ & $\begin{array}{c}{ }^{*} \mathbf{A E} ;{ }^{*} \mathbf{B E} ;{ }^{*} \mathbf{C E} ;{ }^{*} \mathbf{D E}>* \mathbf{B C}>* \mathbf{A B}>\mathbf{C D} \\
0.000 ; 0.000 ; 0.000 ; 0.000>0.0007>0.0123>0.0150\end{array}$ & $\begin{array}{c}* \mathbf{B C E}>\mathbf{A B E}>* \mathbf{C D E} \\
0.0002>0.0028>0.0232\end{array}$ \\
\hline $\mathrm{Al}_{2} \mathrm{O}_{3}$ & $\begin{array}{c}{ }^{*} \mathbf{B} ;{ }^{*} \mathbf{C} ;{ }^{*} \mathbf{D} ;{ }^{*} \mathbf{E}>* \mathbf{A} \\
* * 0.000 ; 0.000 ; 0.000 ; 0.000>0.0249\end{array}$ & $\begin{array}{c}{ }^{*} \mathbf{C E} ;{ }^{*} \mathbf{B E}>* \mathbf{D E}>* \mathbf{B C}>* \mathbf{C D}>* \mathbf{A B} \\
0.0000 ; 0.0000>0.0001>0.0003>0.0050>0.0502\end{array}$ & $\begin{array}{c}{ }^{*} \mathbf{B C E}>* \mathbf{A B D} \\
0.0001>0.0011\end{array}$ \\
\hline $\mathrm{CaO}$ & $\begin{array}{c}{ }^{*} \mathbf{C} ;{ }^{*} \mathbf{E}>A ; \text { D }>\text { B } \\
0.000 ; 0.000>0.0597>0.0738>0.3725\end{array}$ & $\begin{array}{c}* \mathrm{CD} ; * \mathrm{CE} \\
0.0000 ; 0.0000\end{array}$ & $\begin{array}{l}{ }^{*} \mathrm{CDE}>* \mathrm{BDE}>* \mathrm{ADE} \\
0.0000>0.0016>0.0534\end{array}$ \\
\hline $\mathrm{MgO}$ & $\begin{array}{c}{ }^{*} \mathbf{D} ;{ }^{*} \mathbf{E}>\mathrm{A}>\mathrm{C}>\mathrm{B} \\
0.000 ; 0.000>0.3658>0.5494>0.9076\end{array}$ & $\begin{array}{c}{ }^{*} \mathbf{C D}>* \mathbf{B D}>* \mathbf{A D}>* \mathbf{C E} \\
0.0005>0.0048>0.0230>0.0249\end{array}$ & $\begin{array}{l}* \mathbf{C D E}>* \mathbf{B D E}>* \mathbf{A D E} \\
0.0000>0.0005>0.0012\end{array}$ \\
\hline
\end{tabular}

\footnotetext{
*The factors shown in bold are statistically significant.

$* * \mathrm{P}$-value at $95 \%$ confidence level.
} 

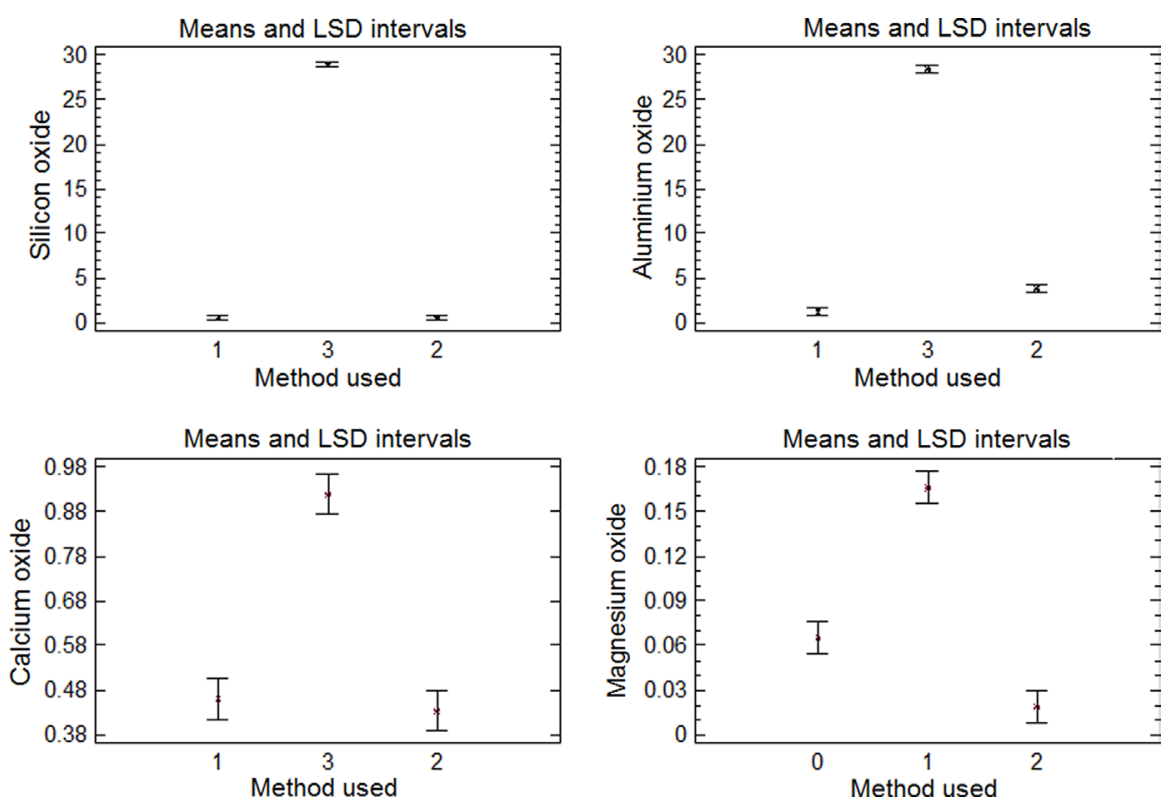

Figure 9. Comparison of dissolution methods used based on the mean solubility of each oxide studied.

The graphs in Figure 9 show that the highest solubility values for all the oxides in glass were attained with chemical process at $80^{\circ} \mathrm{C}$. Only minor differences were observed between the other two methods, except for aluminium and magnesium oxide solubility. Mechano-chemical process proved to be more effective for the former and chemical process at ambient temperature for the latter.

\subsection{Formation of sodium silicate solution from glass waste dissolution. Study by ${ }^{29} \mathrm{Si}$ NMR MAS}

From the previous analytical findings in this work has been proved and quantified the $\mathrm{SiO}_{2}$ contents dissolved from glass wastes. The main objective of this work was to generate solutions of sodium silicates (as potential waterglass solutions) from the different solubilisation process. Figure 10, in turn, reproduces the ${ }^{29} \mathrm{Si}$ NMR spectrum for the original glass (mixed glass) and the spectrum for the liquid obtained after treating the glass waste with $\mathrm{NaOH} /$ $\mathrm{Na}_{2} \mathrm{CO}_{3}$ at $80 \pm 2^{\circ} \mathrm{C}$ for 6 hours. The spectrum for the waste glass contained a single signal at around $-93 \mathrm{ppm}$, indicative of the presence of the $\mathrm{Q}^{4} \mathrm{Si}$ units that characterize silica glass. The spectrum for the post treatment liquid, even at short times, exhibited a single signal at around $-71 \mathrm{ppm}$, associated with the presence of $\mathrm{Q}^{0}$ units, i.e., dissolved Si monomers. This is important because according to the literature [30-32], the effectiveness of Si in waterglass systems a) Glass waste (mixed)

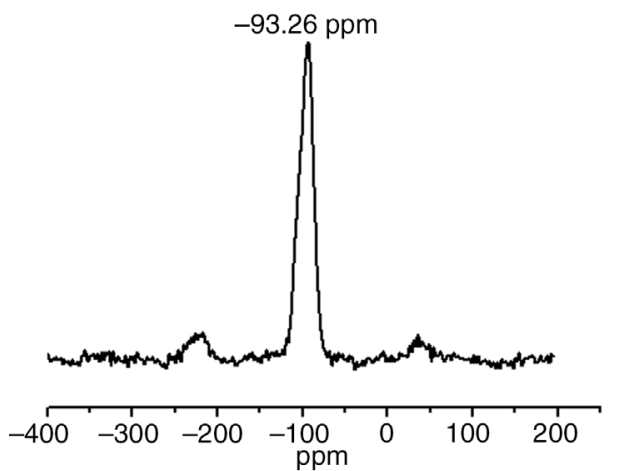

\section{NMR ${ }^{29} \mathrm{Si}$}

b) Liquid after stirring 6 hours at $80 \pm 2^{\circ} \mathrm{C}$

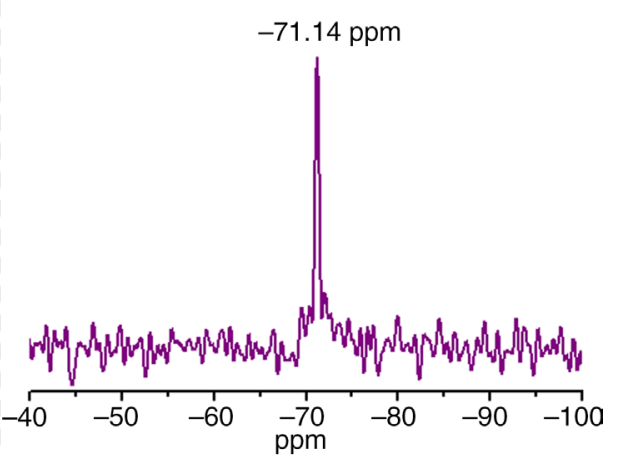

FIGURE 10. ${ }^{29}$ Si MAS NMR spectra for a) untreated solid glass waste; and b) liquid obtained after stirring waste in a $\mathrm{NaOH} / \mathrm{Na}_{2} \mathrm{CO}_{3}$ solution for 6 hours at $80 \pm 2{ }^{\circ} \mathrm{C}$. 
rises with declining condensation and polymerization of the molecule in the medium.

Next step is to demonstrate that these sodium silicate solutions formed from glass wastes can be used as alkaline activator of waterglass family in the preparation of Alkali-Activated Materials (AAMs).

\section{CONCLUSIONS}

The inferences drawn from the analytical and statistical data are listed below.

- Of the three solubilisation methods (at ambient temperature $\left(22^{\circ} \pm 2^{\circ} \mathrm{C}\right)$, at $80^{\circ} \pm 2^{\circ} \mathrm{C}$ and mechano-chemical at ambient temperature) studied, chemical process at $80^{\circ} \mathrm{C}$, delivered the highest $\mathrm{SiO}_{2}$ and $\mathrm{Al}_{2} \mathrm{O}_{3}$ solubility, dissolving around $60 \%$ of the respective oxides.

- The results observed for mechano-chemical and chemical process at ambient temperature were similar.

- In all three methods studied, $\mathrm{SiO}_{2}$ and $\mathrm{Al}_{2} \mathrm{O}_{3}$ solubility rose when stirring time was 6 hours, when the glass particle size was under $45 \mu \mathrm{m}$ and when the alkaline medium was a $\mathrm{NaOH} /$ $\mathrm{Na}_{2} \mathrm{CO}_{3}$ mix.

- The statistical analysis of the percentages of $\mathrm{Si}$, $\mathrm{Al}, \mathrm{Ca}$ and $\mathrm{Mg}$ oxide dissolution confirmed the importance of the factors studied and proved that the activation method used is highly significant in glass dissolution.

- Using the NMR ${ }^{29} \mathrm{Si}$ technique, it has been found that silicon of waste glass dissolved in the dissolution of $\mathrm{NaOH} / \mathrm{Na}_{2} \mathrm{CO}_{3}$ after 6 hours of stirring and with temperature $\left(80 \pm 2^{\circ} \mathrm{C}\right)$ is as $\mathrm{Q}^{0}$ monomers. This is important because after we can use this dissolution to activate materials such as slag or fly ash and the results will be very similar when using a commercial waterglass solution.

\section{ACKNOWLEDGEMENTS}

This research was funded by the Spanish Ministry of the Economy and Competitiveness under project BIA2010-15516. Thanks to C. Carrillo for her assistance with the ICP analyses and P. Rivilla for her aid with the laboratory trials.

\section{REFERENCES}

1. Chesner, W.H.; Collins, R.J.; MacKay, M.H. (1997) User Guidelines for Waste and By-product Materials in Pavement Construction, US Department of Transportation, Federal Highway Administration, Publication. FHWA-RD-97-148.

2. Caijun, S.; Keren, Z. (2007) A review on the use of waste glasses in the production of cement and concrete. Resources Conservation and Recycling, 52, 234-247. http://dx.doi. org/10.1016/j.resconrec.2007.01.013.

3. Guohua, C.; Harry, L.; King, L.Y.; Po, L.Y.; Adolf, W.; Thomas, T.M.; Ka, K.C. (2002) Glass recycling in cement production-an innovative approach. Waste Management, 22, 747-753.

4. Ecovidrio 2012. http://www.ecovidrio.es/.

5. Shi, C.; Wu, Y.; Riefler, C.; Wang, H. (2005) Characteristics and pozzolanic reactivity of glass powders. Cem. Concr. Res. 35 [5], 987-993. http://dx.doi.org/10.1016/j.cemconres. 2004.05.015

6. Andreola, F.; Barbieri, L.; Karamanova, E.; Lancellotti, I.; Pelino, M. (2008) Recycling of CRT panel glass as fluxing agent in the porcelain stoneware tile production. Ceramics International, 34, 1289-1295. http://dx.doi. org/10.1016/j.ceramint.2007.03.013.

7. Luz, A.P.; Riberio, S. (2007) Use of glass waste as a raw material in porcelain stoneware tile mixtures. Ceramics International, 33, 761-765. http://dx.doi.org/10.1016/j. ceramint.2006.01.001.

8. Chester, W.H. (1992) Waste glass and sludge for use in asphalt pavement. Utilization of Waste Materials in Civil Engineering Construction, 296-307.

9. Gorokhovski, A.V.; Escalante-García, J.I.; Gashnikova Yu.; Nikulina, L.P.; Artemenko, S.E. (2005) Composite materials basse on wastes of flan glass processing. Waste Management, 25,733-736. http://dx.doi.org/10.1016/j.wasman.2004.11.007.

10. Torres, J.J.; Palacios, M.; Hellouin, M.; Puertas, F. (2009) Alkaline chemical activation of urban glass to produce cementitiuous materials. $1^{a}$ Conferencia sobre Reciclado de Materiales y Eco-Energía (RECIMAT 09), 110-114.

11. Torres-Carrasco, M.; Puertas, F.; Blanco-Varela, M.T. (2012) Preparación de cementos alcalinos a partir de residuos vítreos. Solubilidad de residuos vítreos en medios fuertemente básicos. XII Congreso Nacional de Materiales (Alicante).

12. Puertas, F. (1995) Cementos de escorias activadas alcalinamente: Situación actual y perspectivas de futuro. Mater. Construcc. 45 [239], 53-66. http://dx.doi.org/10.3989/ mc.1995.v45.i239.553.

13. Shi, C.; Kryvenko, P.V.; Roy Della. (2006) Alkali-activated cements and concretes. Ed. Taylor \& Francis.

14. Puertas, F.; Fernández-Jiménez, A.; Blanco-Varela, M.T. (2004) Pore solution in alkali-activated slag cement pastes. Relation to the composition and structure of calcium silicate hydrate. Cem. Concr. Res. 34, 139-148. http://dx.doi. org/10.1016/S0008-8846(03)00254-0.

15. Puertas, F.; Martínez-Ramirez, S.; Alonso, S.; Vázquez, T. (2000) Alkali-activated fly ash/slag cement. Strength behaviour and hydration products. Cem. Concr. Res. 30, 16251632. http://dx.doi.org/10.1016/S0008-8846(00)00298-2.

16. Puertas, F.; Fernández-Jiménez, A. (2003) Mineralogical and microstructural characterization of alkali-activated fly ash/slag pastes. Cem. Concr. Comp. 25 [3], 287-292. http:// dx.doi.org/10.1016/S0958-9465(02)00059-8.

17. Sánchez, R.; Palacios, M.; Puertas, F. (2011) Characteristics and properties of oil-well cements additioned with blast furnace slag. Mater. Construcc. 61 [302], 185-211. http:// dx.doi.org/10.3989/mc.2010.54110.

18. Mejía, J.M.; Mejía de Gutiérrez, R.; Puertas, F. (2013) Rice husk ash as silica source in fly ash and ground blast furnace slag cementitious alkali activated systems. Mater. Construcc, 63 [311], 361-375. http://dx.doi.org/10.3989/mc.2013.04712.

19. Van Deventer, J.S.J.; Provis, J.L.; Duxson, P.; Bride, D.G. (2010) Chemical research and climate changes as drivers in the commercial adoption of alkali activated materials. Waste Biomass Valor. 1, 145-155. http://dx.doi.org/10.1007/ s12649-010-9015-9.

20. Van Deventer, J.S.J.; Provis, J.L.; Duxon, P. (2012) Technical and commercial progress in the adoption of geopolymer cement. Minerals Engineering, 29, 89-104. http://dx.doi. org/10.1016/j.mineng.2011.09.009.

21. Fernández-Jiménez, A.; Puertas, F.; Palomo, J.G. (1999) Alkali-activated slag mortars: mechanical strength behavior. Cem. Concr. Res. 29, 593-604. http://dx.doi. org/10.1016/S0008-8846(99)00154-4.

22. Larosa-Thomson, J.; Gill, P.; Scheetz, B.E.; Silsbee, M.R. (1997) Sodium silicate applications for cement and concrete. Proc. 10th Int. Congr. On the Chemistry of Cement, Gothenburg, 3.3. 
23. Ralph K. Iler. (1979) The chemistry of Silica. Solubility, polymerization, colloid and surface properties and biochemistry. John Wiley \& Sons, Inc. ISBN 0-471-02404-X.

24. Fernández Navarro, J.M. (2003) El vidrio. Consejo Superior de Investigaciones Científicas. Sociedad Española de Cerámica y Vidrio. Madrid.

25. T.M. El-Shamy;; Panteno, C.G. (1977) Descomposition of silicate glasses in alkaline solutions. Nature, 266, 704-706. http://dx.doi.org/10.1038/266704a0

26. El-Shamy, T.M.; Lewis, J.; Douglas, R.W. (1972) The dependence on the $\mathrm{pH}$ of the descomposition of glasses by aqueous solutions. Glass Technology, 13, 81-87.

27. Paul, A. (1977) Chemical durability of glasses; a thermodynamic approach. Journal of materials science, 12, 22462268. http://dx.doi.org/10.1007/BF00552247.

28. K. Goto, J. (1955) States of silica in aqueous solution II Solubility of amorophous silica. Chem. Soc. Jap. Pure Chem Sect, 76, 1364-1366.
29. Stanworth, J.E. (1950) Physikalische Eigenschaften und Struktur von Gläsern. Glastech 23, 297-304.

30. Engelhardth, G.; Michel, D. (1987) High Resolution Solid State NMR of Silicates and Zeolites. Wiley, Chichester, UK.

31. Criado, M.; Fernández-Jiménez, A.; Palomo, A.; Sobrados, I.; Sanz, J. (2008) Effect of the $\mathrm{SiO}_{2} / \mathrm{Na}_{2} \mathrm{O}$ ratio on the alkali activation of fly ash. Part II: ${ }^{29}$ Si MAS-NMR" Survey, Microporous and Mesoporous Materials 109 [1-3], 525534. http://dx.doi.org/10.1016/j.micromeso.2007.05.062.

32. Palomo, A.; Fernández-Jiménez, A.; Criado, M. (2004) Geopolímeros: una única base química y diferentes microestructuras. Mater. Construcc. 54, 275. http://dx.doi. org/10.3989/mc.2004.v54.i275.249.

33. Ruiz-Santaquiteria, C.; Torres-Carrasco, M.; Alonso, M.M.; Puertas, F. (2013) Valorización de residuos vítreos en la elaboración de morteros alcalinos. Workshop on Environmental Impact of Buildings Construction, Universidad Politécnica de Madrid. 